\title{
Analisis Laporan Keuangan dengan Model Z-Score sebagai Alat dalam Memprediksi Bankcruptcy (Studi Kasus pada PT. Ramayana Lestari Sentosa Tbk, PT. Matahari Putra Prima Tbk, dan PT. Mitra Adiperkasa Tbk)
}

\author{
Muhammad Rahmatullah $^{1}$, Erry Sunarya ${ }^{2}$, Dicky Jhoansyah ${ }^{3}$ \\ ${ }^{123}$ Fakultas Ilmu Administrasi dan Humaniora, Universitas Muhammadiyah Sukabumi
}

\begin{abstract}
This study aims to determine the modified Altman z-score model can predict the possibility of bankcruptcy at PT. Ramayana Lestari Sentosa Tbk, PT. Matahari Putra Prima Tbk and PT. Mitra Adiperkasa Tbk, which is incorporated into Aprindo (Indonesian Retail Entrepreneurs Association), which is experiencing shifting consumption patterns. This study uses a quantitative approach descriptive analysis technique that is used to systematically describe bankcruptcy predictions after calculating using number that are entered into the Altman modification z-score formula. The result of the study show that theoretically there are 1 company in the bankcruptcy category and 2 companies in the non-bankcruptcy category. For companies that are already in a non-bankcruptcy category can maintan an existing management system, for comapnies that are in the bankcruptcy category, management must immediately make the right subscription if they don't want the company to experience bankcruptcy.
\end{abstract}

Keywords : Financial statement analysis, Model z-score, Bankcruptcy prediction

Abstrak

Penelitian ini bertujuan untuk mengetahui model z-score modifikasi Altman dapat memprediksi kemungkinan bankcruptcy pada PT. Ramayana Lestari Sentosa Tbk, PT. Matahari Putra Prima Tbk dan PT. Mitra Adiperkasa Tbk yang termarsuk kedalam Aprindo (Asosiasi Pengusaha Ritel Indonesia), yang sedang mengalami shifting pola konsumsi masyarakat. Penelitian ini menggunakan teknik analisis deskriptif pendekatan kuantitatif yang digunakan untuk mendeskripsikan secara sistematis prediksi bankcruptcy setelah melakukan perhitungan menggunakan angka-angka yang dimaksukan kedalam rumus z-score modifikasi Altman. Hasil penelitian menunjukan bahwa diketahui secara teoritis ada 1 perusahaan berada dalam kategori bankcruptcy dan 2 perusahaan yang berada dalam kategori non bankcruptcy. Untuk perusahaan yang sudah berada dalam kategori non bankcruptcy dapat mempertahankan sistem manajemen yang sudah ada, untuk perusahaan yang berada dalam kategori bankcruptcy, manajemen harus segera melakukan penangganan yang tepat jika tidak ingin perusahaan mengalami bankcruptcy.

Kata Kunci : Analisis laporan keuangan, Model z-score, Prediksi bankcruptcy

\section{PENDAHULUAN}

Saat ini, perkembangan bisnis ritel yang begitu pesat, akan melahirkan suatu persaingan yang ketat. Perusahaan yang ingin berusaha terus berkembang dan maju di zaman milenial ini, harus siap melakukan strategi dan memahami keinginan para pelaku konsumen. Dari sisi lain, melihat perkembangan teknologi yang begitu pesat di zaman milenial ini dimana teknologi sudah dipakai dengan sebaik mungkin untuk berbisnis, disebabkan pada zaman sekarang bisnis online sudah tidak asing lagi bagi kalangan pelaku konsumen, dan itu jelas akan mempunyai dampak persaingan yang semakin ketat pada pangsa pasar perusahaan ritel. Oleh karena itu, untuk mempertahankan eksistensi maupun keberlangsungan hidup perusahaan ritel di zaman milenial ini pihak manajer senantiasa harus pintar melakukan strategi yang bertujuan untuk mempertahankan perolehan pendapatan perusahaan.

Salah satu untuk mengetahui keberlangsungan hidup suatu perusahaan yakni dengan melakukan analisa sedini mungkin untuk memprediksi bankcruptcy apabila perusahaan sedang mengalami kesulitan dalam masalah keuangan. Prediksi bankcruptcy bertujuan untuk memberikan panduan kepada pihak-pihak manajer maupun perusahaan mengenai kinerja dari suatu perusahaan apakah akan mengalami kesulitan dalam hal keuangan, sebab apabila suatu perusahaan sudah mengalami suatu kesulitan keuangan maka bisa saja akan menimbulkan suatu bankcruptcy pada perusahaan tersebut. Untuk itu, perusahaan harus melakukan sedini mungkin untuk melakukan analisa dalam memprediksi bankcruptcy dengan melihat pada laporan keuangan suatu perusahaan.

Laporan keuangan merupakan suatu data berupa angka-angka, data tersebut mempunyai 
manfaat bagi pihak-pihak yang akan melakukan sebuah kepentingan maupun pengambilan keputusan pada suatu perusahaan. Sebab dengan melakukannya sebuah analisa laporan keuangan suatu perusahaan akan mempunyai manfaat untuk pihak manajer terutama dalam menilai maupun melakukan evaluasi.

Dalam penelitian ini peneliti akan mencoba memprediksi suatu bankcruptcy dengan menggunakan model z-score Altman pada PT. Ramayana Lestari Sentosa Tbk, PT. Matahari Putra Prima Tbk dan PT. Mitra Adiperkasa Tbk yang terdaftar di BEI, ketiga perusahaan tersebut adalah perusahaan yang bergerak dalam bidang ritel yang telah masuk dalam Aprindo (Asosiasi Pengusaha Ritel Indonesia) yang sedang mengalami shifting pola konsumsi masyarakat yang mengakibatkan ketiga perusahaan tersebut tidak berhasil menghasilkan pendapatan sesuai dengan target perusahaan (Aprindo, 2017).

Ditambah pula dengan dipilihnya ketiga perusahaan yang bergerak dalam industri ritel dikarenakan pada salah satu perusahaan tersebut mengalami gejala-gejala yang mungkin menimbulkan suatu bankcruptcy, disebabkan laba bersih dan nilai ekuitas pada salah satu perusahaan mengalami penurunan pada tiap tahunnya. Berikut adalah grafik yang yang menggambarkan kondisi laba bersih dan nilai ekuitas pada PT. Ramayana Lestari Sentosa Tbk, PT. Matahari Putra Prima Tbk dan PT. Mitra Adiperkasa Tbk periode 2013-2017 :

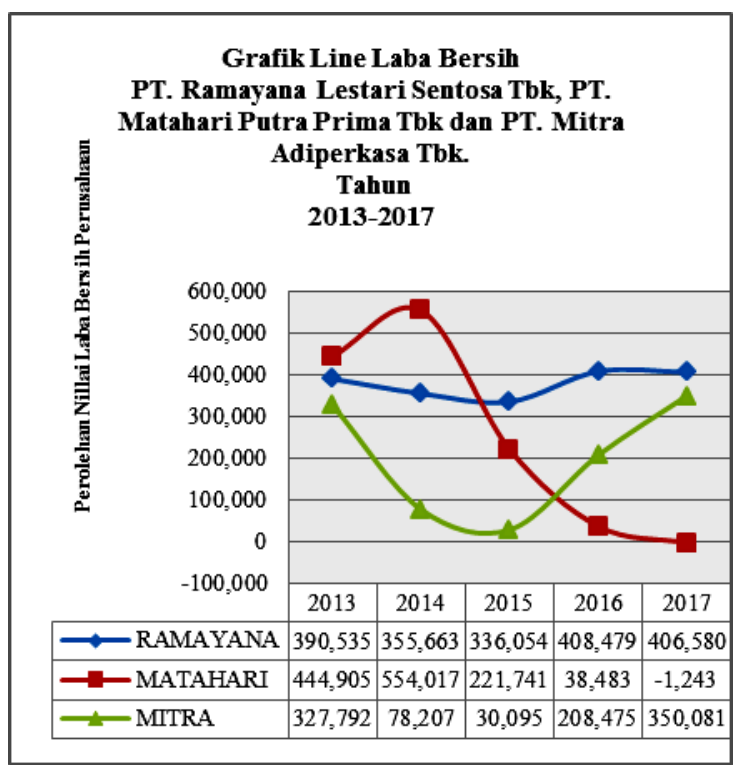

Gambar 1 grafik laba bersih PT. Ramayana Lestari Sentosa Tbk, PT. Matahari Putra Prima Tbk dan PT. Mitra Adiperkasa Tbk periode 2013-2017 Sumber : Laporan keuangan, data sekunder diolah, 2018

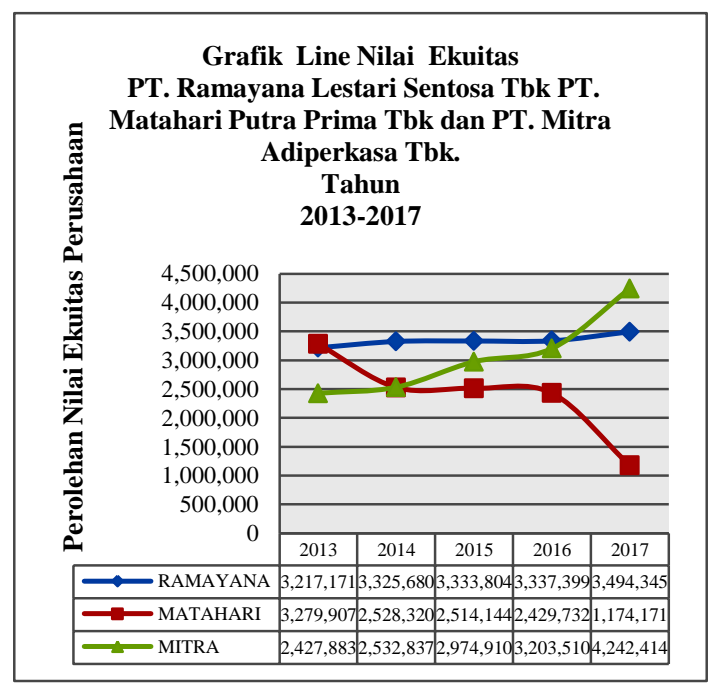

Gambar 2 grafik nilai ekuitas PT. Ramayana Lestari Sentosa Tbk, PT. Matahari Putra Prima Tbk dan PT. Mitra Adiperkasa Tbk periode 2013-2017 Sumber: Laporan keuangan, data sekunder diolah, 2018

Dari gambar grafik laba bersih dan nilai ekuitas diatas diketahui bahwa pada PT. Matahari Putra Prima Tbk terjadi penurunan laba bersih selama 3 (tiga) tahun berturut-turut yakni pada tahun 2015 sampai 2017, dan yang lebih menjadi permasalan yaitu di tahun 2017 laba bersih pada PT. Matahari Putra Prima Tbk bernilai negatif, ditambah dengan nilai ekuitas dari PT. Matahari Putra Prima Tbk mengalami penurunan selama 4 (empat) tahun berturut-turut yakni pada tahun 2014-2017, yang mana kondisi tersebut bisa termasuk kedalam tanda-tanda bankcruptcy.

Firda Mastuti, Muhammad Saifi dan Devi Farah Azizah (2013), menganalisis estimasi kebangkrutan perusahaan plastik dan kemasan dengan metode altman z-score menunjukan hasil bahwa terdapat 1 perusahaan dinyatakan dalam estimasi bangkrut $(Z<1,81), 2$ diantaranya dalam estimasi rawan $(1,81<Z<2,99)$ dan 2 perusahaan lainnya berada dalam kondisi sehat $(Z>2,99)$.

Selanjutnya penelitian Aminah dan Andi Sanjaya (2013), menunjukan bahwa model altman z-score tepat digunakan untuk memprediksi kebangkrutan pada perusahaan perbankan go-public di Indonesia.

Dan penelitian Tiara Weni Arista dan Triyonowati (2016), menganalisis prediksi kebangkrutan pada perusahaan ritel go-public dengan metode altman z-score menunjukkan bahwa dari lima perusahaan sampel, 1 perusahaan di prediksi berpotensi bangkrut $(\mathrm{Z}<1,1), 1$ perusahaan di prediksi rawan bangkrut $(1,1<\mathrm{Z}<2,6)$, dan 3 perusahaan lainnya berada pada kondisi sehat $(\mathrm{Z}>2,6)$.

Berdasarkan hasil penjajagan yang peneliti lakukan, ditemukan permasalahan bahwa pada PT. Ramayana Lestari Sentosa penurunan laba bersih selama 2 tahun, PT. Matahari Putra Prima Tbk 
terjadi penuruanan laba bersih 3 tahun berturutturut serta dibarengi dengan penurunan nilai ekuitas selama 4 tahun berturut-turut. Sementara untuk PT. Mitra Adiperkasa Tbk mengalami penurunan laba bersih selama 2 tahun. Sebab, laba bersih merupakan salah satu tolak ukur keberhasilan perusahaan dalam pencapaian tujuannya, selain itu laba bersih ialah salah satu komponen untuk mengukur kinerja keuangan suatu perusahaan apakah sedang berada pada keadaan baik atau tidaknya kondisi keuangan perusahaan tersebut. Kondisi keuangan perusahaan dapat dilihat melalui laporan keuangan perusahaan dengan melihat laporan keuangan pihak-pihak yang terlibat dapat mengetahui apakah perusahaan sedang mengalami bankcruptcy atau tidak.

Berdasarkan latar belakang penelitian yang telah diuraikan diatas, maka rumusan masalah dalam penelitian ini bisa dirumuskan sebagai berikut: "Bagaimana model Z-Score modifikasi dapat memprediksi bankcruptcy pada PT. Ramayana Lestari Sentosa Tbk, PT. Matahari Putra Prima Tbk, dan PT. Mitra Adiperkasa Tbk yang termasuk dalam Aprindo?"Adapun tujuan dari penelitian ini adalah untuk mengetahui model zscore modifikasi dapat memprediksi banckruptcy pada PT. Ramayana Lestari Sentosa Tbk, PT. Matahari Putra Prima Tbk dan PT. Mitra Adiperkasa Tbk.

\section{KAJIAN LITERATUR}

\section{Bankcruptcy}

"Kebangkrutan telah digunakan sebagai istilah umum untuk menerangkan keadaan perusahaan yang mengalami kesulitan keuangan" (Karel Praskah, 2014 dalam Sihombing).

Ross, et al (1999:917) menyatakan bahwa "financial distress" sebagai ketidakmampuan perusahaan memenuhi kewajiban-kewajibannya (insolvency).

Hal yang tidak jauh berbeda juga disampaikan oleh Toto Prihadi (2014). Menurut Toto Prihadi (2014:332), "kebangkrutan (bankcruptcy) merupakan kondisi di mana perusahaan tidak mampu lagi untuk melinasi kewajibannya".

Sedangkan menurut Supardi dalam Nafisatin (2014:2) "kebangkrutan (bankcruptcy) biasanya diartikan sebagai kegagalan perusahaan dalam menjalankan operasi perusahaan untuk menghasilkan laba".

Berdasarkan beberapa pendapat yang dikemukakan diatas peneliti menyimpulkan bahwa bankcruptcy adalah keadaan dimana perusahaan gagal atau tidak mampu menghasilkan laba optimal dalam pemanfaatan operasional perusahaan dan keadaan ketika perusahaan tidak mampu membayar kewajiban-kewajiban perusahaan serta ketidak cukupan dana yang dimiliki perusahaan untuk melanjutkan usahanya.

\section{Pengertian Laporan Keuangan}

Menurut Kasmir (2014:7): “Laporan keuangan adalah laporan yang menunjukkan kondisi keuangan perusahaan pada saat ini atau dalam suatu periode tertentu".

Menurut Munawir (dalam Irham Fahmi 2013:22): "Laporan keuangan merupakan alat yang sangat penting untuk memperoleh informasi sehubungan dengan posisi keuangan dan hasil-hasil yang telah dicapai oleh perusahaan yang bersangkutan".

Sedangkan menurut Irham Fahmi (2013:22) menyatakan bahwa: "Laporan keuangan merupakan suatu informasi yang menggambarkan kondisi suatu perusahaan, dimana selanjutnya itu akan menjadi suatu informasi yang menggambarkan tentang kinerja suatu perusahaan".

Berdasarkan pengertian menurut para ahli tersebut, dapat disimpulkan bahwa laporan keuangan adalah hasil akhir dari proses akuntansi yang berbentuk angka-angka dan tentunya dari hasil angka-angka tersebut bisa menggambarkan kondisi keuangan perusahaan, hasil operasi suatu perusahaan, dan lebih jauh dapat digunakan untuk mengetahui kinerja perusahaan juga memperkirakan laba yang dapat diperoleh perusahaan di masa depan.

\section{Model Prediksi Bankcruptcy}

"Prediksi kebangkrutan usaha berfungsi untuk memberikan panduan bagi pihak-pihak mengenai kinerja keuangan perusahaan apakah akan mengalami kesulitan keuangan atau tidak dimasa mendatang" (Darsono dan Ashari, 2015:105).

perusahaan bisa menghindari dari suatu resiko bankcruptcy dengan melakukan suatu analisa keadaan keuangan perusahaan melalui prediksi bankcruptcy dengan metode altman z-score modifikasi yaitu:

\section{Model Altman Modifikasi (1995)}

Menurut Hery, (2017:39) menyatakan bahwa "model Z-Score modifikasi dapat diterapkan pada semua perusahaan, seperti manufakture, non manufacture dan perusahaan penerbit obligasi dalam hal memprediksi kebangkrutan".Untuk menganalisis prediksi bankcruptcy pada perusahaan, maka dapat dilakukan dengan menggunakan model Z-Score modifikasi ditambah dengan data laporan keuangan berupa neraca dan laporan laba rugi. Data hasil perhitungan dari rasiorasio tersebut kemudian akan dianalisis lebih jauh dengan menggunakan formula yang telah di modifikasi oleh Altman yaitu:

Z-score $=6,56 x_{1}+3,26 x_{2}+6,72 x_{3}+1,05 x_{4}$

Sumber: Hery Kajian Riset Akuntansi, 2017. 
Keterangan:

$\mathrm{X}_{1} \quad=$ Working capital/total asset

$\mathrm{X}_{2} \quad=$ Retained earnings/ total asset

$\mathrm{X}_{3} \quad=$ Earning before interest and taxes/ total asset

$\mathrm{X}_{4} \quad=$ Book value of equity/ book value of total debt

Klasifikasi perusahaan yang sehat dan bangkrut didasarkan pada nilai Z-score model Altman yang sudah di Modifikasi, yaitu:

1. Bila $Z>2,6=$ Zona "Aman" (Pada kondisi ini, perusahaan berada pada kondisi yang sehat sehingga kecil kemungkinan terjadi kebangkrutan).

2. Bila $1,11<Z<2,6=$ Zona "Abu-abu" (Pada kondisi ini, perusahaan mengalami financial distress yang harus ditangani dengan penanganan managemen yang tepat. Jika terlambat, dan tidak tepat penanganannya, perusahaan dapat mengalami kebangkrutan. Jika pada zona abu-abu ini ada kemungkinan perusahaan bangkrut atau berjuang dari masa financial distress).

3. Bila $Z<1,11=$ Zona "Distress" (Pada kondisi ini, perusahaan mengalami financial distress dan beresiko tinggi mengalami kebangkrutan) Dalam penelitian kali ini model z-score Altman yang digunakan untuk memprediksi bankcruptcy pada PT. Ramayana Lestari Sentosa Tbk, PT. Matahari Putra Prima Tbk dan PT. Mitra Adiperkasa Tbk yang terdaftar di BEI yakni dengan menggunakan model z-score modifikasi.

\section{METODE PENELITIAN}

Metode penelitian yang digunakan peneliti untuk menemukan dan mendapatkan sebuah jawaban untuk masalah yang di teliti adalah metode penelitian deskriptif dengan pendekatan kuantitatif. Dengan maksud, dalam penelitian ini peneliti akan mengambarkan atau menyimpulkan suatu prediksi bankcruptcy setelah melakukan perhitungan melalui model z-score modifikasi.

Data penelitian terdiri dari data sekunder. Yaitu data yang diperoleh secara tidak langsung dari situs web.idx.id dan www.idx.id yakni berupa data laporan keuangan PT. Ramayana Lestari Sentosa Tbk, PT. Matahari Putra Prima Tbk dan PT. Mitra Adiperkasa Tbk dalam periode 20132017, yang dijadikan unit analisis dengan menggunakan teknik yang ada, maupun dari sumber yang di teliti serta data yang di dapat dari buku dan informasi lainnya maupun kepustakaan

\section{HASIL PENELITIAN DAN PEMBAHASAN}

Perhitungan z-score modifikasi pada PT. Ramayana Lestari Sentosa Tbk, PT. Matahari Putra
Prima Tbk dan PT. Mitra Adiperkasa Tbk yang diteliti dapat dilihat pada tabel di bawah ini:

Tabel Perhitungan Z-Score Periode 2013

\begin{tabular}{|c|c|c|}
\hline No & $\begin{array}{c}\text { Kode } \\
\text { Perusahaan }\end{array}$ & Perhitungan \\
\hline 1 & RALS & $\begin{array}{l}\text { Z-score }=6,56 \mathrm{X}_{1}+3,26 \mathrm{X}_{2}+ \\
6,72 \mathrm{X}_{\mathrm{a}}+1,05 \mathrm{X}_{4} \\
=6,56(0,3223)+3,26(0,6128)+ \\
6,72(0,1045)+1,05(2,7701) \\
=2,114+1,997+0,702+2,908 \\
=7,751 \quad \text { (prediksi non } \\
\text { bankcruptcy) }\end{array}$ \\
\hline 2 & MPPA & $\begin{array}{l}\text { Z-score }=6,56 \mathrm{X}_{1}+3,26 \mathrm{X}_{2}+ \\
6,72 \mathrm{X}_{a}+1,05 \mathrm{X}_{4} \\
=6,56(0,1718)+3,26( \\
0,3379)+6,72(0,0889)+1,05(1 \\
, 003) \\
=1,127+1,101+0,597+1,053 \\
=3,878 \text { (prediksi non } \\
\text { bankcruptcy) }\end{array}$ \\
\hline 3 & MAPI & $\begin{array}{l}\text { Z-score }=6,56 \mathrm{X}_{1}+3,26 \mathrm{X}_{2}+ \\
6,72 \mathrm{X}_{\mathrm{a}}+1,05 \mathrm{X}_{4} \\
=6,56(0,06)+3,26(0,2011)+6, \\
72(0,0621)+1,05(0,4512) \\
=0,393+0,655+0,417+0,473 \\
=1,938 \text { (prediksi grey area) }\end{array}$ \\
\hline
\end{tabular}

Sumber: Laporan keuangan, hasil pengolahan data, 2019

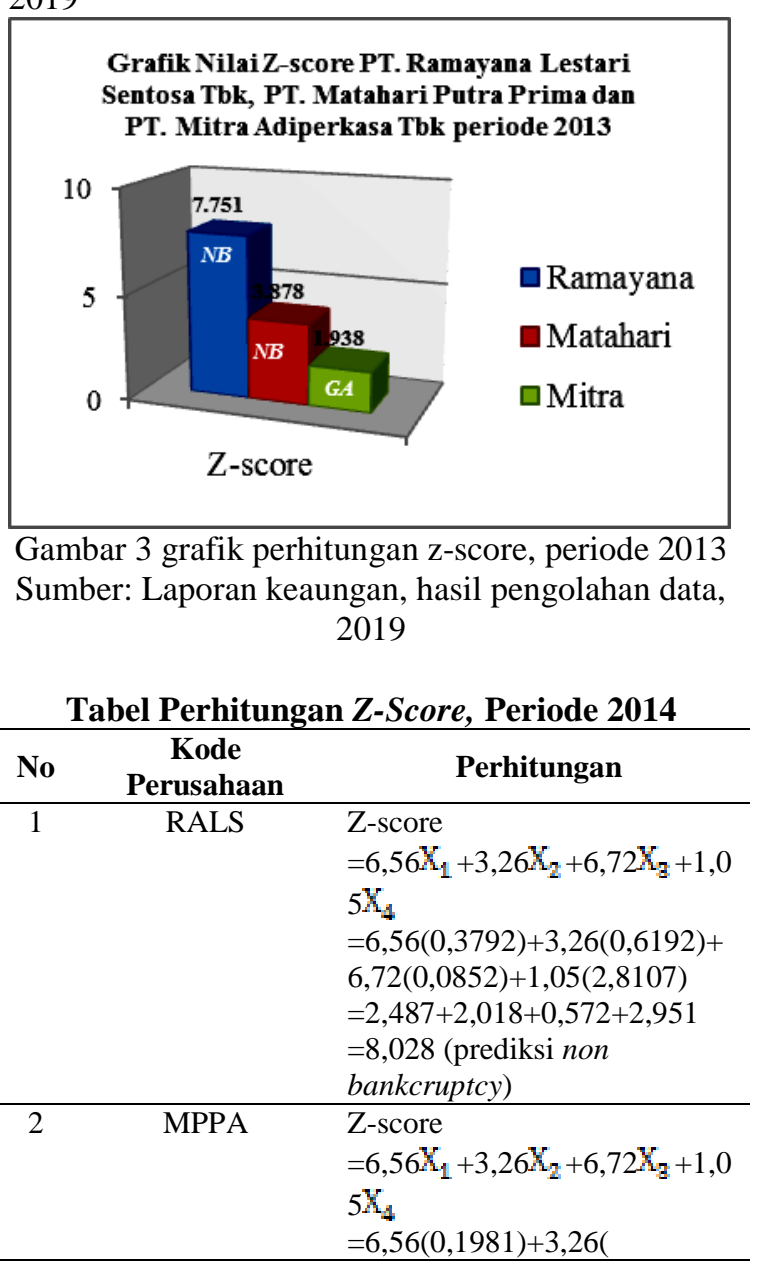




\begin{tabular}{|c|c|c|}
\hline No & $\begin{array}{c}\text { Kode } \\
\text { Perusahaan }\end{array}$ & Perhitungan \\
\hline & & $\begin{array}{l}0,3046)+6,72(0,1254)+1,05(0, \\
9563) \\
=1,299+0,992+0,842+1,004 \\
=4,137 \text { (prediksi } \text { non } \\
\text { bankcruptcy) }\end{array}$ \\
\hline 3 & MAPI & $\begin{array}{l}\text { Z-score } \\
=6,56 \mathrm{X}_{1}+3,26 \mathrm{X}_{2}+6,72 \mathrm{X}_{\mathrm{a}}+1,0 \\
5 \mathrm{X}_{4} \\
=6,56(0,1519)+3,26(0,1849)+ \\
6,72(0,022)+1,05(0,4294) \\
=0,996+0,602+0,147+0,450 \\
=2,195 \text { (prediksi grey area) }\end{array}$ \\
\hline
\end{tabular}

Sumber: Laporan keuangan, hasil pengolahan data, 2019

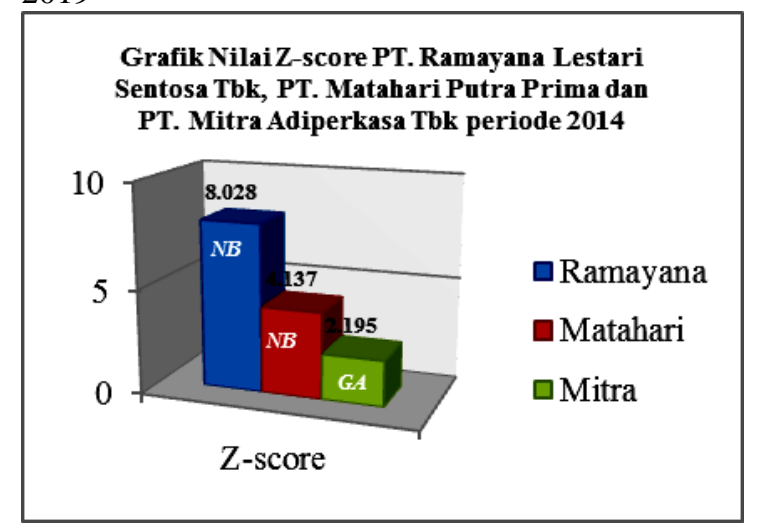

Gambar 4 grafik perhitungan z-score, periode 2014 Sumber: Laporan keuangan, hasil pengolahan data, 2019

Tabel Perhitungan Z-Score, periode 2015

\begin{tabular}{|c|c|c|}
\hline No & $\begin{array}{c}\text { Kode } \\
\text { Perusahaan }\end{array}$ & Perhitungan \\
\hline 1 & RALS & $\begin{array}{l}\text { Z-score } \\
=6,56 \mathrm{X}_{1}+3,26 \mathrm{X}_{2}+6,72 \mathrm{X}_{\mathrm{a}}+1,0 \\
5 \mathrm{X}_{4} \\
=6,56(0,4088)+3,26( \\
0,6503)+6,72(0,0797)+1,05(2, \\
6861) \\
=2,681+2,119+0,535+2,820 \\
=8,155 \text { (prediksi } \text { non } \\
\text { bankcruptcy) }\end{array}$ \\
\hline 2 & MPPA & $\begin{array}{l}\text { Z-score } \\
=6,56 \mathrm{X}_{1}+3,26 \mathrm{X}_{2}+6,72 \mathrm{X}_{\mathrm{a}}+1,0 \\
5 \mathrm{X}_{4} \\
=6,56(0,1837)+3,26( \\
0,2701)+6,72(0,037)+1,05(0,7 \\
888) \\
=1,205+0,880+0,248+0,828 \\
=3,161 \text { (prediksi } \text { non } \\
\text { bankcruptcy) }\end{array}$ \\
\hline 3 & MAPI & $\begin{array}{l}\text { Z-score } \\
=6,56 \mathrm{X}_{1}+3,26 \mathrm{X}_{2}+6,72 \mathrm{X}_{\mathrm{a}}+1,0 \\
5 \mathrm{X}_{4} \\
=6,56(0,2536)+3,26( \\
0,1741)+6,72(0,0156)+1,05(0, \\
4571) \\
=1,663+0,567+0,104+0,479 \\
=2,813 \text { (prediksi } \text { non } \\
\text { bankcruptcy) }\end{array}$ \\
\hline
\end{tabular}

Sumber: Laporan keuangan, hasil pengolahan data, 2019

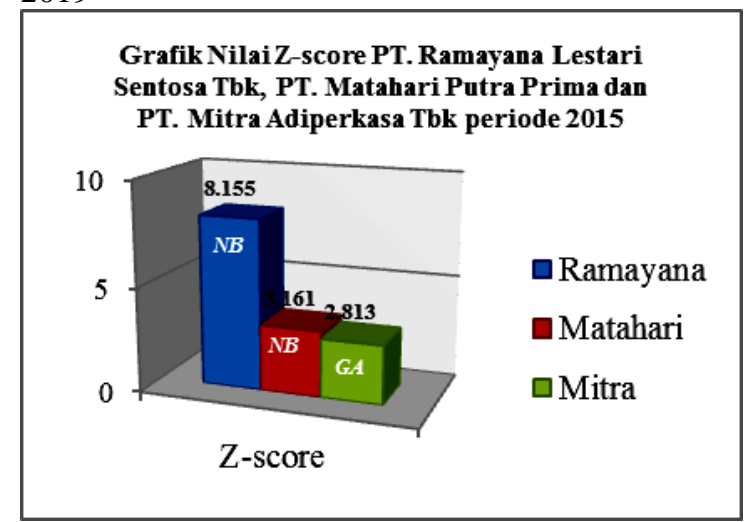

Gambar 5 grafik perhitungan z-score, periode 2015 Sumber: Laporan keuangan, hasil pengolahan data, 2019

Tabel Perhitungan Z-Score, periode 2016

\begin{tabular}{|c|c|c|}
\hline No & $\begin{array}{c}\text { Kode } \\
\text { Perusahaan }\end{array}$ & Perhitungan \\
\hline 1 & RALS & $\begin{array}{l}\text { Z-score } \\
=6,56 \mathrm{X}_{1}+3,26 \mathrm{X}_{2}+6,72 \mathrm{X}_{2}+1,0 \\
5 \mathrm{X}_{4} \\
=6,56(0,392)+3,26( \\
0,6836)+6,72(0,1)+1,05(2,548 \\
3) \\
=2,571+2,228+0,672+2,675 \\
=8,146 \text { (prediksi } \text { non } \\
\text { bankcruptcy) }\end{array}$ \\
\hline 2 & MPPA & $\begin{array}{l}\text { Z-score } \\
=6,56 \mathrm{X}_{1}+3,26 \mathrm{X}_{2}+6,72 \mathrm{X}_{\mathrm{a}}+1,0 \\
5 \mathrm{X}_{4} \\
=6,56(0,1146)+3,26( \\
0,2017)+6,72(0,015)+1,05(0,5 \\
687) \\
=0,751+0,657+0,100+0,597 \\
=2,105 \text { (prediksi grey area })\end{array}$ \\
\hline 3 & MAPI & $\begin{array}{l}\text { Z-score } \\
=6,56 \mathrm{X}_{1}+3,26 \mathrm{X}_{2}+6,72 \mathrm{X}_{\mathrm{a}}+1,0 \\
5 \mathrm{X}_{4} \\
=6,56(0,2279)+3,26( \\
0,174)+6,72(0,0375)+1,05(0,4 \\
282) \\
=1,495+0,567+0,252+0,449 \\
=2,763 \text { (prediksi } \text { non } \\
\text { bankcruptcy) }\end{array}$ \\
\hline
\end{tabular}

Sumber: Laporan keuangan, hasil pengolahan data, 2019

\begin{tabular}{|c|c|c|}
\hline $\begin{array}{c}\text { Grafik Nilai Z-score PT. Ramayana Lestari } \\
\text { Sentosa Tbk, PT. Matahari Putra Prima dan } \\
\text { PT. Mitra Adiperkasa Tbk periode 2016 }\end{array}$ \\
\hline \\
\hline
\end{tabular}


Gambar 6 grafik perhitungan z-score, periode 2016 Sumber: Laporan keuangan, hasil pengolahan data, 2019

Tabel Perhitungan Z-Score, periode 2017

\begin{tabular}{|c|c|c|}
\hline No & $\begin{array}{c}\text { Kode } \\
\text { Perusahaan }\end{array}$ & Perhitungan \\
\hline 1 & RALS & $\begin{array}{l}\text { Z-score } \\
=6,56 \mathrm{X}_{1}+3,26 \mathrm{X}_{2}+6,72 \mathrm{X}_{a}+1, \\
05 \mathrm{X}_{4} \\
=6,56(0,418)+3,26( \\
0,683)+6,72(0,0953)+1,05(2, \\
5003) \\
=2,742+2,226+0,640+2,625 \\
=8,233 \quad \text { (prediksi non } \\
\text { bankcruptcy) }\end{array}$ \\
\hline 2 & MPPA & $\begin{array}{l}\text { Z-score } \\
=6,56 \mathrm{X}_{1}+3,26 \mathrm{X}_{2}+6,72 \mathrm{X}_{9}+1, \\
05 \mathrm{X}_{4} \\
=6,56(-0,2561)+3,26( \\
0,0174)+6,72(- \\
0,3076)+1,05(0,276) \\
=(-1,680)+0,056+(- \\
2,067+0,289 \\
=(-3,402) \\
\text { bankcruptcy) }\end{array}$ \\
\hline 3 & MAPI & $\begin{array}{l}\text { Z-score } \\
=6,56 \mathrm{X}_{1}+3,26 \mathrm{X}_{2}+6,72 \mathrm{X}_{\mathrm{a}}+1, \\
05 \mathrm{X}_{4} \\
=6,56(0,1955)+3,26( \\
0,188)+6,72(0,0522)+1,05(0, \\
5906) \\
=1,282+0,612+0,350+0,620 \\
=2,864 \quad \text { (prediksi non } \\
\text { bankcruptcy) }\end{array}$ \\
\hline
\end{tabular}

Sumber: Laporan keuangan, hasil pengolahan data, 2019

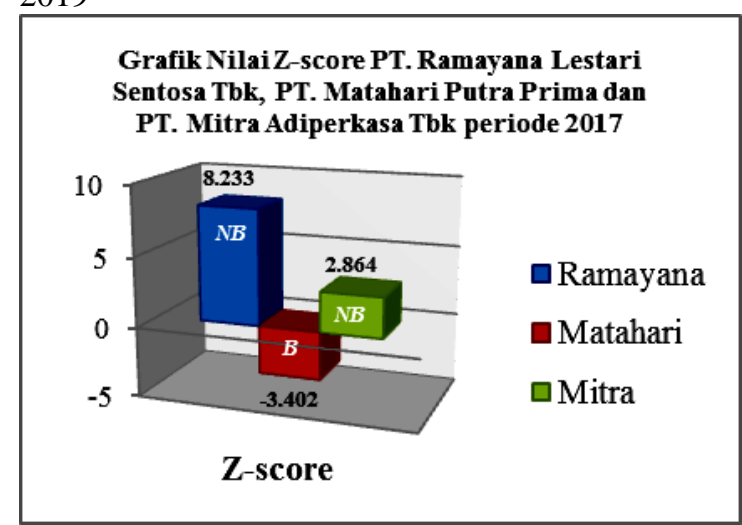

Gambar 6 grafik perhitungan z-score, periode 2017 Sumber: Laporan keuangan, hasil pengolahan data, 2019

Keterangan:

$\begin{array}{ll}\text { NB } & \text { : Non Bankcurptcy } \\ \text { GA } & : \text { Grey Area } \\ \text { B } & : \text { Bankcruptcy }\end{array}$

Dari hasil perhitungan prediksi bankcruptcy menggunakan model z-score modifikasi pada PT.
Ramayana Lestari Sentosa Tbk, PT. Matahari Putra Prima Tbk dan PT. Mitra Adiperkasa Tbk yang terdaftar di Bursa Efek Indonesia (BEI) periode 2013-2017 membuktikan bahwa perhitungan menggunakan model z-score dapat digunakan untuk memprediksi atau mengetahui bagaimana kondisi perusahaan saat ini apakah sedang mengalami bankcruptcy atau tidak. Dari hasil perhitungan menggunakan model z-score pada PT. Ramayana Lestari Sentosa Tbk termasuk kedalam perusahaan yang masuk dalam kategori "non bankcruptcy". Perusahaan yang berada dalam kategori tersebut menggambarkan bahwa kondisi keuangan perusahaan dalam keadaan sehat dan kecil kemungkinan perusahaan mengalami bankcruptcy. Untuk PT. Matahari Putra Prima Tbk ditahun 2013 sampai dengan tahun 2015 masuk kedalam perusahaan yang termasuk dalam posisi kategori "non bankcruptcy" karena dari hasil perhitungan menggunakan model z-score menghasilkan bahwa nilai z-score perusahaan berada pada titik aman. Di tahun 2016, perusahaan masuk kedalam kategori "grey area" yang disebabkan nilai z-score $>1,1$ dan $<2,6$ yang tentunya dengan hasil tersebut maka perusahaan masuk kedalam kategori "grey area". Namun di tahun 2017 perusahaan mengalami penurunan $\mathrm{X}_{1}, \mathrm{X}_{2}, \mathrm{X}_{2}, \mathrm{X}_{4}$ sehingga nilai $\mathrm{Z}$-score $<1,1$ yang tentunya dengan hasil tersebut bisa dikatakan bahwa perusahaan berada dalam kondisi maupun masuk kategori "bankcruptcy". Untuk PT. Mitra Adiperkasa Tbk di tahun 2013 sampai 2014 perusahaan masuk kedalam perusahaan yang berada pada kategori "grey area", hal tersebut dikarenakan nilai $\mathrm{z}$-score menghasilkan $>1,1$ dan $<2,6$ dari kriteria z-score sendiri, "grey area" artinya kondisi keuangan perusahaan tidak bisa diketahui apakah mengalami bankcruptcy atau tidak. Namun di tahun 2015 sampai 2017 PT. Mitra Adiperkasa Tbk berada dalam kategori "non bankcruptcy" disebabkan perolehan nilai z-score mengalami kenaikan dengan hasil dari nilai z-score yakni > 2,6 dari kriteria nilai z-score. Dengan kejadian tersebut bisa diketahui bahwa perusahaan sedang mengalami kondisi keuangan yang berkembang secara perlahan.

\section{PENUTUP}

\section{Kesimpulan}

Dari hasil perhitungan menggunakan model zscore modifikasi altman pada PT. Ramayana Lestari Sentosa Tbk, termasuk kedalam perusahaan yang berada pada zona "Non Bankcruptcy". Perusahaan yang berada dalam zona tersebut menggambarkan bahwa kondisi keuangan suatu perusahaan dalam keadaan sehat dan kecil kemungkinan perusahaan mengalami bankcruptcy. Untuk PT. Matahari Putra Prima Tbk. Pada tahun 2013 sampai tahun 2015 perusahaan masuk kedalam kategori atau zona "Non Bankcruptcy" 
disebabkan dari hasil perhitungan akhir menggunakan model z-score modifikasi menghasilkan nilai $\mathrm{z}$-score perusahaan berada pada titik aman. Dan ditahun tahun 2016 perusahaan mengalami suatu penurunan $X_{1}, X_{2}, X_{3}, X_{4}$, sehingga kondisi perusahaan berada pada kategori "Grey Area". Namun pada tahun 2017 PT. Matahari Putra Prima Tbk kembali mengalami penurunan yang serius pada nilai $\mathrm{X}_{1}, \mathrm{X}_{2}, \mathrm{X}_{3}, \mathrm{X}_{4}$, yang mengakibatkan hasil akhir perhitungan model Z-score modifikasi menghasilkan nilai $\mathrm{Z} \quad<1,1$ tentunya dengan kejadian tersebut perusahaan berada pada posisi "Bankcruptcy". Untuk PT. Mitra Adiperkasa Tbk di tahun 2013 sampai tahun 2014 perusahaan masuk kedalam kategori atau zona "Grey Area", hal ini dikarenakan pada tahun 2014 terjadi penurunan $\mathrm{X}_{1}, \mathrm{X}_{2}, \mathrm{X}_{3}, \mathrm{X}_{4}$, namun pada tahun 2015 sampai dengan tahun 2017 terjadi peningkatan pada PT. Mitra Adiperkasa Tbk sehingga kondisi perusahaan berada pada kategori "Non Bankcruptcy" ini disebabkan adanya peningkatan yang signifikan pada nilai $\mathrm{X}_{1}, \mathrm{X}_{2}, \mathrm{X}_{3}$, $\mathrm{X}_{4}$, setiap tahunnnya.

\section{Saran}

1. Perusahaan senantiasa harus selalu mengecek laporan keuangan setiap akhir tahun dikarenakan untuk melihat dan meramal kontinuitas maupun kelangsungan hidup perusahaan dimasa yang akan datang. Dengan terdeteksinya kondisi keuangan perusahaan yang bermasalah dari awal, maka pihak perusahaan harus segera melakukan langkahlangkah antisipasi terhadap pencegahan agar kondisi keuangan suatu perusahaan segera teratasi dengan cepat, tepat, dan akurat sehingga bisa terhindar dari kebangkrutan.

2. Perusahaan harus mampu meningkatkan volume dari penjualan agar pendapatan yang dihasilkan lebih tinggi dan meningkatkan pengelolaan aktivitas perusahaan agar laba yang dihasilkan bisa lebih tinggi.

3. Perusahaan harus mampu mengalokasikan dana perusahaan seefektif mungkin sesuai dengan kebutuhan dari perusahaan.

\section{DAFTAR PUSTAKA}

Arikunto, S. (2014). Prosedur Penelitian Suatu Pendekatan Praktik. Jakarta: Rineka Cipta.

Arista Tiara Weni. (2016). "Analisis Diskriminan Altman Z-Score Untuk Memprediksi Kebangkrutan Pada Perusahaan Ritel Go Public". Jurnal Ilmu dan Riset Manajemen, 5, (2), 1-16.

Darsono dan Ashari. (2005). Dalam Pedoman Praktis Memahami Laporan Keuangan. Jakarta: Salemba Empat.
Endri. (2014). Prediksi Kebangkrutan Bank untuk Menghadapi dan Mengelola Perubahan Lingkungan Bisnis: Analisis Model Altman's Z-Score. Perbanas Qurterly riview, 1, (2), 34-50.

Fahmi Irham. (2012). Dalam E. Pertama, Analisis Laporan Keuangan. Bandung: Alfabeta.

Hanafi Mamduh. (2007). Dalam E. Pertama, Manajemen Keuangan. Yogyakarta: BPFE.

Hery. (2017). Kajian Riset Akuntansi. Jakarta: Grasindo.

Maya, D. 2014 Prediksi Kebangkrutan Perusahaan Asuransi Syariah Berdasarkan Metode Altman Z-Score. Skripsi S1 pada FSH. UIN Syarif Hidayatullah Jakarta, Tidak di terbitkan.

Munawir, S. (2007). Dalam E. Kedua, Analisis Laporan Keuangan. Yogyakarta: YPKN.

Nazir. (2014). Metode Penelitian. Bogor: Ghalia Indonesia.

Praditia, A. (2017). "Memprediksi Financial Distress Dengan Menggunakan Kinerja Keuangan Dan Model Altman Pada Industri Semen Di BEI". E-Jurnal Surabaya: Sekolah Tinggi Ilmu Ekonomi Indonesia (STIESIA).

Prihadi, T. (2010). Dalam Analisis Laporan Keuangan (Teori dan Aplikasi). Jakarta: PPM.

Ross Stephen A., Westerfield Randolph W., dan Jeffrey. (1999). Corporate Finance. New York: The McGraw-Hill Companies, Inc.

Sagho Maria Florida, M. N. (2015). "Penggunaan Metode Altman Z-Score Modifikasi Untuk Memprediksi Kebangkrutan Bank Yang Terdaftar Di Bursa Efek Indonesia". EJurnal Akuntansi Universitas Udayana, 11, (3), 730-742.

Sugiyono. (2014). Dalam Metode Penelitian (Pendekatan Kuantitatif, Kualitatif, dan R\&D. Bandung: Alfabeta..

\section{Profil Penulis :}

1. Muhammad Rahmatullah, Mahasiswa Fakultas Ilmu Administrasi dan Humaniora, Universitas Muhammadiyah Sukabumi. Email : rahmatullah648@gmail.com

2. Dr. Erry Sunarya, M. Si, Dosen Fakultas Ilmu Administrasi dan Humaniora, Universitas Muhammadiyah Sukabumi. Email : errysoen@gmail.com 
3. Dicky Jhoansyah, SE., MA, Dosen Fakultas Ilmu Administrasi dan Humaniora, Universitas Muhammadiyah Sukabumi.

Email : dicky.jhoansyah@gmail.com 